\title{
A REVIEW OF JURISPRUDENTIAL ARGUMENTS FOR THE PERMISSIBILITY OF TORTURE IN ISLAM
}

\author{
Mohsen $\mathrm{Razmi}^{1}$ \\ Morteza Enferadi Kolarkatteh ${ }^{2}$
}

\begin{abstract}
Human dignity is the common aspect of all divine religions. Torture is an issue that has targeted human dignity. Thus, it is remembered as crime against humanity in many cultures and rules. Islam has always insisted on respect for humans. But in Islamic sources, there are documents (including direct and indirect arguments) that convey the permissibility of torture to the mind and make the audience doubt or at least contemplate in this regard. Deep thinking about its principles can be responsive to these ambiguities.

The present study is a new and fundamental research which has been conducted based on library studies and seeks to answer, explore and demystify the arguments for the permissibility of torture.

Study of the documentation demonstrates that the hypothesis of torture permissibility in Islam has been accepted as a "particular affirmative proposition". The necessity of this type of research is that dynamic jurisprudence, when responding to challenges, must actively explain its positions with strong arguments.
\end{abstract}

Keywords: Torture, Islam, arguments, permissibility

\section{INTRODUCTION}

God has created mankind as the superior of the creatures. This inherent dignity for human being requires that he should not be subjected to torture or other cruel treatments. Hence, whenever a person is tortured, this is nothing but denying human dignity and honor.

The thought of preserving and safeguarding human dignity has always been considered by scholars and thinkers throughout history and legislatures have required themselves to comply with it since violations of human body and soul have not been accepted in any religion, school or culture and in general, every human being innately hates disrespecting his own kind.

Torture is an illegitimate affair and a crime against humanity and many legislative measures have been taken in the international and regional arena to prevent it. Nevertheless, study of why governments sometimes

\footnotetext{
${ }^{1}$ Corresponding Authors, Assistant Professor and Faculty Member of Jurisprudence \& Islamic Law, Mashhad Branch, Islamic Azad University, Mashhad, Iran. E-mail: Razmi@nnfan.com

2 Ph.D Student of Jurisprudence and Principles of Law, Mashhad Branch, Islamic Azad University, Mashhad, Iran. E-mail: Enferad91@outlook.com
} 
turn to torture and how they justify it is among the important questions that make the mind explore this issue. This subject is much more important in Islamic topics.

\subsection{Statement of the problem}

Today, despite the prohibition of torture, we practically observe that many countries claiming respect for human rights inflict torture in many cases and try to justify it.

In Islamic jurisprudence and criminal law, with reliance on divine revelations, any oppression, torture, mistreatment or violation is prohibited because man has been introduced as having a high position (worshipped by angels; Surah Baqarah, Verse 39) and being God's caliph (Surah Baqarah, Verse 32). Therefore, any violation of his dignity is forbidden and there is a consensus on its prohibition in various jurisprudential chapters and in many cases. However, among the jurisprudential arguments and documents, there are instances in which the permissibility of torture is inferred from the word and manner of the infallible Imams (AS) and this makes the audience doubt or at least contemplate.

The problem is how the instances of torture permissibility in Islam can be interpreted or how the inaccuracy of those arguments can be examined or how the application of torture prohibition in Islam should be conditioned and the permissibility of torture be accepted in some cases. The main focus of this study is to explore and demystify this hypothesis.

\subsection{Necessity and significance}

This type of issues is of great importance, especially given the gaps existing in Islamic jurisprudence and criminal law (in which there is no comprehensive definition of torture) and its significant impact on guiding the audience's minds particularly at this point of time when the issue of human rights in international assemblies has become a leverage to apply pressure on Islamic teachings and on the other hand, the issue of torture has been legal in many ages and has undergone many periods in the international system to reach this stage of legislative development.

Another point is that before the Islamic Revolution, jurisprudence (Fiqh) did not play an effective role in government and only assumed the responsibility of responding to personal and individual areas. But after the Revolution, jurisprudence was officially manifested in the text of laws and was exposed to public view while enjoying government sanctions. So, jurisprudence, in the face of needs and challenges, is required to respond and issues such as torture should get out of the abstract mode and their associated provisions should be practiced and 
applied since it is necessary that in the process of challenging ideologies with the deep reconsideration of concepts, dynamic jurisprudence realize its comprehensiveness using the components resulting from the quadruple arguments in the real world and the world of instances.

\section{RESEARCH THEORETICAL FOUNDATIONS}

In the opinion of a freethinker, torture is innately contrary to the common sense. Apart from religion, when man looks at this issue as a human being, he shows his disgust in some way. Even many Western scholars in the field of applied ethics have condemned this practice.

Montesquieu believes that,

In multiple governments, good lawmakers try to inflict less punishment for crimes and attempt to prevent the occurrence of crimes and teach people good morals instead of torturing them and adding to their hardship and severity of the punishment. (Montesquieu, 1970: 197)

Brissot, French politician, lawyer and journalist and the representative of Parisian people in the House of Representatives, states that,

Torture is an immoral and inhuman act and obtaining confessions by terrible and brutal experiments is specific to the age of ignorance and the adoption of such methods in the era of civilization and among humanitarian people is barbaric and against nature, religion, philosophy and logic. (Peymani, 1977: 65)

Beccaria argues that,

Torture is one of the instances of anti-social acts and will lead to the reaction of societies. Thus, any incentive to inflict torture is unacceptable. As long as someone has not been proven guilty, society should not hesitate to support him and should not allow an innocent person to confess because of pain. If someone's guilt is proved, torture is not necessary but legal penalty is sufficient. (Beccaria, 1989:27)

Therefore, In addition to religious scholars and experts in legal matters, those who are also theoreticians in the field of ethics endorse the ugliness of torture.

Given that Islam as the most complete religion considers a moral aspect for punishment (in addition to jurisprudential and legal issues), it believes that the maintenance of human dignity is necessary and any violation of people's rights is disapproved. The basis of this ruling is a number of Quranic verses, narratives, consensus and reason, and the documentation for the criminalization of this phenomenon has explicitly been stated in it. But among some of the elders' documentation and statements, there are materials indicating that in certain circumstances, immediate and more important benefits may arise so that the application of torture is permissible. However, not only this view exists among Islamic scholars and thinkers but also some of the Western theorists 
have confirmed it. For example, some lawyers in their theories advocate offensive and violent actions by many governments, including the United States, and argue that the use of torture is exceptionally justified in some emergency situations. They believe that the government must try to obtain information from any terrorist who has endangered the lives of innocent people (Shafi'ei-niya, 2009: 177).

The philosophy of allowing torture is similar among its supporters (whether Islamic or non-Islamic) and has the same content. They have based their arguments on the usefulness of this method and have tried to find a rational basis for it. In addition to usefulness, they have stated that the urgency of governments' need to achieve immediate and vital facts and lack of responsiveness and adequacy of conventional methods of gaining information are the reasons for justifying the use of torture. They have also maintained that the only way to prevent heavy damages is the administration of torture, while resorting to the rule of prevention of probable loss and applying easier methods. The priority of collective interests is another reason resulting in the use of torture by religious and secular schools. But it should be noted that in many cases, torture may lead to false confessions and information (Levin, 1998: 178).

As previously mentioned, torture is a way to achieve the certainty of the truth based on force; if the person is strong and adapts to the pain, he is considered innocent and if he is weak, he will be recognized as a culprit (Cassese, 1998: 82).

\section{RESEARCH FINDINGS}

What makes people contemplate in this respect is the hadiths and manner of the infallible Imams (AS) which have become a basis for the permissibility or justification of torture among some Islamic scholars.

Documents for the permissibility of torture are divided into two groups:

Arguments that directly convey the permissibility of torture

Arguments that indirectly convey the permissibility of torture

Each of these two categories has its own instances along with its relevant documentation, which are stated in detail below.

\section{Direct arguments for the permissibility of torture}

This category of arguments is in the form of narratives, utterances or acts of the infallible Imams (AS) and is of multiple types: 


\section{The story of Kinana ibn Abi al-Haqiq}

Ibn Abi al-Haqiq was the chief of the Jews of Khaybar who compromised with the Prophet (PBUH) regarding his own and his tribe's safety in return for all his property. When the Prophet asked about their treasures, they said that they spent the treasure for the war. Then, the Prophet asked Tsa'labah bin Salam about the treasure. He said: "I do not know but Ibn Abi al-Haqiq visited such and such a ruin every day". When the Prophet found the treasure, he ordered Zubair to torture him so that he introduces the rest of the property. Zubair tortured him to the extent that he brought a flint and tormented him with fire. It is said in this story, “... أمر رسول الله الزبير ان يعذّب "كنانه ابن ابى الحقيق حتى يستخر كل ماعنده فعذبه الزبير حتى جاءه بزند يقدمه فى صدره (Vaqedi, 1985, 671/2).

In this historical case mentioned in the resources, the Prophet directly ordered Zubair to torture Ibn Abi al-Haqiq.

\section{The case of Ibn Rabi'}

The chief of the Jews of Bani Nadhir who refused to tell the treasure hiding place was tortured at the فأمر رسول الله (ص) الزبير بن العو ام. فقال: عذّبه حتى تستأصل ماعنده. فكان الزبير يقدح بزند ... Prophet's command يصدره حتى اشرف على نفسه..... (Ameli, 2005, 50/18).

God's Messenger ordered Zubair bin Awam to torture him so that he confesses everything. Zubair lit fire on his chest and tormented him with fire to death.

\section{The case of Hatib bin Abi Balta'ah}

This story is related to a woman who hid Hatib's letter in her hair and the Prophet ordered Ali (AS) and ما كذب ... Zubair to obtain that letter and when they did not find the letter after the initial inspection, Ali (AS) said:

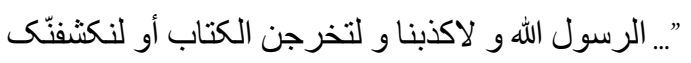

This narrative has been mentioned with several different phrases such as لاقتلنّك (Ravandi, 1989, 162/1),

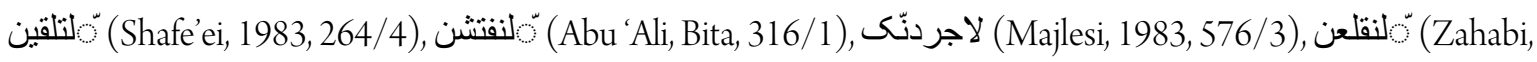
1987, 526/2), لتنزعن" (Ghazzali, Bita, 139/7), which show that Ali (AS) tried to find the letter by intimidating and threatening to murder or making naked.

Below this case, the following has been mentioned in some resources: "وفيها جواز تجريد المرأة كلّها " وتكثقةها للحاجة و المصلحة العامّة (Mousavi Lakenhoi, Bita, 384/4). 


\section{The case of Hamza}

On the day of Uhud, the Prophet (PBHU), after seeing the mutilated body of Hamza, said: ".... ما وققت . موققاً قط اغيظ على من هذا لمكان لئن امكننى الله من قريش لامثلن سبعين رجلاً منهم ..." (Feiz Kashani, 1995, 164/3).

The mutilation which is one of the most horrible forms of torture has been mentioned in the word of the Prophet who decided to mutilate seventy people of the Quraysh in return for the mutilation of Hamza, his uncle, and murmured the phrase "I mutilate" three times (Tabatabaei, 2017, 404/12).

\section{Hadith}

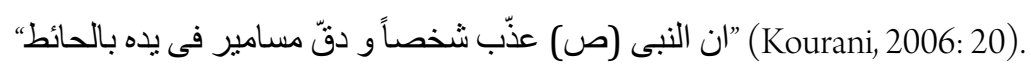

The Prophet tortured a person while nailing his hand to the wall. This prophetic hadith also leaves no doubt that the permissibility of torture existed in Islam and was common in the manner of the Prophet.

\section{Hadith of Soleiman bin Khalid}

In the hadith of Soleiman bin Khalid, Imam Sadiq (AS) said: " سألت اباعبدالله عن رجل سرق فكابر عنها فضرب فجاء بها عينها هل يجب عليه القطع؟ قال نعم (Mottaqi Hendi, Bita, 404/5).

Imam Sadiq (AS) was questioned about the thief who, after being tortured, brought the stolen property: Is the prescribed punishment obligatory for him? Imam said: Yes.

The permissibility of torture is also inferred from this narrative since if torture was condemned in Islam, Imam should remark about its prohibition while it is not the case. So, the silence and utterance of Imam is the basis for the prescription of torture. From these arguments, it is concluded that torture has a special place in the tradition and manner of the infallible Imams as well as Muslim scholars and thinkers. The above arguments explicitly and directly state the permissibility of torture in Islam.

\section{Indirect arguments for the permissibility of torture}

Some jurisprudents have stated such matters as maintaining the authority of the Islamic regime, establishing security and so on for the permissibility of torture and have relied on jurisprudential rules and principles accepted by reason and religion to argue for this theory. The most important indirect arguments for the 
permissibility of torture are as follows:

\section{The rule of necessity}

Sometimes, a particular condition forces a person to commit prohibited acts and abandon some obligatory matters. Under such circumstances, primary rules lose their actuality and are an instance of the rule of necessity. This rule, which governs ${ }^{3}$ other jurisprudential rules and provisions, is also a license for torture.

This rule has Quranic (Baqarah: 173; Ma'idah: 3; An'am: 119) and narrative documentation such as hadith of Raf al-Qalam (Sadouq, 1983: 417), Mu'tabarah Sama'a (Horre Ameli, 1993, 373/4), Mufadhal narrative (Barqi, 1912, 334/2) and also the arguments of reason and manner of intellectuals.

The application of this rule embraces, in addition to torture, the permissibility of murder in some cases. For example, “لو تترسو ا بالاسارى من المسلمين و ان قتل الاسير اذا لم يكن جهادهم الَّ كذلك" (Najafi, 1988, 68/21).

If infidels use Muslim captives as shields and jihad (holy war) with them is only possible through the killing of captives, it is permissible.

\section{The rule of important and the more importante}

This rule states that whenever there is a conflict between two orders, the more important order is, by reason, preferred (A group of researchers, 2010, 613/1).

In this rule, an obligatory matter may become prohibited and a prohibited matter may become obligatory and in the encounter between expediency and mischief, their place may sometimes be changed: "....

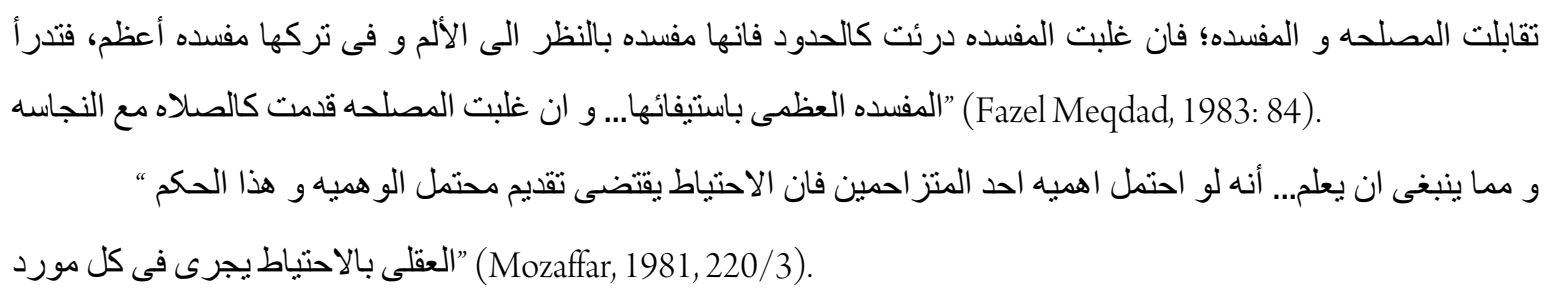

In this sense, we can say that in some cases, a single act has multiple and multilateral effects and consequences and is subject to different rules, which sometimes the observance of one requires the violation of another. In such cases of conflict, two task-oriented and goal-oriented approaches can be considered. Bombing

\footnotetext{
${ }^{3}$ If one argument provides for another argument and describes and interprets its content, it is called a rule, whether the second argument provides for the subject of the rule or develops or restricts it and whether the implication is in terms of conformity or obligation or is early or late. In such cases, the governing argument is called the ruler and the considered argument is called the ruled (Meshkini, 2015: 161).
} 
civilian areas to win a legitimate war and torturing and assassinating the opponents and enemies of a legitimate government are examples with dual effects (Bahrami \& Faramarz Qaramaleki, 2012: 36). Therefore, if an issue is of significant importance, such as the maintenance of the system, in which low probability is incontrovertible and assuming that the maintenance of the system is dependent on the defendant's punishment to disclose the issue, then the permissibility of punishment of the accused can be accepted because according to the rule of conflict, the expediency of an important and obligatory matter interferes with a prohibited matter whose mischief is not as obligatory as its expediency and accepting the first one is preferable (Salavati, 1991, 577/3).

Thus, the Islamic rules being based on a series of expediency and mischief in terrestrial terms (i.e. related to man, available to human revelation, reason and science) on one hand and the Islamic legislation system including factual propositions (i.e. it took the rule on general titles not individuals) on the other provide the mujtahid with the possibility of giving different fatwas at different times and places based on the order of Islam and discovering that something which is lawful at one time is forbidden, obligatory or recommended at the other time (Motahhari, 1991,31/2).

In addition to the intellectual argument, other arguments like Quranic verses (Nahl: 106) and the manner of intellectuals are among the documentation of this rule.

Hence, the Guardian Council has presented this theory:

In the conflict between the important and the more important and between the more corrupt and the corrupt one, the rational and religious rule is to prefer the more important and avoid the more corrupt. So, in some cases like kidnapping or bombing, the judge, according to the evidence, documents and arguments, may deem it necessary to issue a ruling on information gathering to save the lives of a large number of people (Mousavi, 2003: 36).

The rule of the avoidance of the more corrupt by the corrupt one

The basis of this rule is the need to act based on the corrupt one in the face of the more corrupt: "هذه

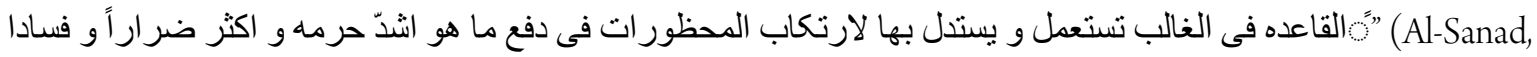
2005: 268).

This rule has documentation from Quran (Nisa: 148; Hud: 78; Baqarah: 217; Fath: 25; Kahf: 74, 80; Yusuf: 7) and narratives such as arrogance against the arrogant (Alousi, Bita, 61/9), Tadavi hadiths (Najafi, 1988) and arguments of the reason and consensus and manner of intellectuals and also the Prophet's tradition. The importance and application of this rule is such that even at the time of drafting the constitution of the Islamic 
Republic of Iran, it has been cited for the permissibility of torture. Ayatollah Meshkini, one of the decision-makers in this meeting, says:

... Some issues need to be addressed; for example, probably some of the important characters have been kidnapped and we know two or three people who are aware of the kidnappers and if they are slapped, it might be discovered. Is torture prohibited in such cases?... If they are tortured like this, they tell the story. For instance, in the event of Professor Motahhari, there is an individual who probably knows the assailant. If you tell him whether he knows or not, he says no ... Isn't the issue of the avoidance of the more corrupt by the corrupt one true in such cases given that it existed in the past? (Proceedings of the negotiations of the constitutional assembly, 1985, $777 / 1)$

Exactly the same issue has been accepted by Western thinkers for the permissibility of torture under the title "The ticking time bomb scenario" and they deem it necessary:

A terrorist has placed a bomb somewhere in New York City and this bomb will explode a few hours later and will kill many citizens. The terrorist is arrested but does not speak about the bomb location.

The question is: Are you allowed to torture the terrorist if you are certain that he will disclose the bomb location in this way? Seemingly, the answer is that not only you are allowed to do this but also it is a moral obligation for you (Bail, 2012: 246).

\section{Torture in terms of politics and general interests}

Some Islamic scholars have stated conditions and justifications for the permissibility of torture. This group has considered the permissibility of torture as one of the politics matters and believes that the competent authority to inflict torture is exclusively rulers (Ibn Abedin, 1994, 245/4). Even they state that beating the accused and using different means to detect a crime are among the duties of rulers (Ibn Rouzbehan, 1983: 221, 228). Thus, the survival of the Islamic system and its interests cause that sometimes, many of the primary rules are laid aside to maintain security or avoid chaos and the initial prohibition of some affairs is overlooked. This basis even accounts for confessions under torture to preserve the authority of the government. "... أيّ جريمه افحش من كتمان "حقى هو فى صالح المسلمين و فى كتمانه على كيان الآّه (Araqi, Bita, 364).

For this subject, they have argued with regard to the verse "لاتكتمو الثهاده" (Baqarah: 140) and numerous hadiths and with the reliance on this argument of some jurisprudents. If a person is accused by evidence, this causes that the permissibility of torture is ordered. For example, someone who has a bad background or lacks credibility and good reputation can be tortured to access his information (Ibn Tariyah, 2003: 
$345)$.

In the book "Al-Ahkam al-Sultaniyyah", by dividing people into known as benevolent, known as mischievous and unknown, individuals who are known for their mischief can be tortured if accused.

... For instance, if the charge that is raised is adultery and on the other hand, the accused is also one of those who take orders from women and is humorous and tricky and there are signs of beating in his body or when arresting, he has some equipment with him, then the charge is strong and the ruler has the right to whip the accused not for the prescribed punishment but for Ta'zir so that he is forced to tell the truth (Rules of governance, Maverdi, 2002: 438).

Also, in the book "Al-Iqrar fi Ahkam al-Qazaeiyyah", it is mentioned that "where the accused is known for corruption and does not confess and there is no other reason to prove the right of the person whose property has been stolen, it is necessary that the accused is tormented to confess; otherwise, people's rights are violated (Samakiyya, 1970, 428/1).

Hence, general interests together with politics can pave the way for applying torture. In this regard, there is a narrative from the Prophet, which says: " اذا اجتمعت الحرمتان طرحت الصغرى للكبرى در شرح اين كلام كفته اندا "أى اذا كان امر فيه منفعه للناس و مفسده على الخاصه قدمت مصلحه العامه (Ibn Asir, 1985, 374/1).

On the same subject, it is stated that there is no problem for the ruler to threaten to kill the criminals who are not entitled to be killed since this threat is for intimidating them (Salavati, 1991, 572/3).

In the book "Information and research in Islam", it is mentioned that any act that interrupts the system is not permissible and any act leading to the maintenance of the system is necessary and the necessity of maintaining order or prohibiting disturbance has different means in authorities and other people (according to their status) (Ahmadi Miyanji, 2001: 19).

\section{Torture for quitting the obligatory matter}

In Islamic principles and arguments, quitting the obligatory matter is one of the cases for which torture is permissible in Islamic jurisprudence. This issue has been mentioned in many jurisprudential chapters. For example:

- Threat to burn in case of Ila’4 (Najafi, 1988, 316/33).

- Torture with hunger and thirst in case of Ila' (Sadouq, 1984, 524/3).

- Torture in case of Zehar ${ }^{5}$ (Helli, 1992, 186/2).

\footnotetext{
${ }^{4}$ The husband swears to refrain from having sex with his wife for the purpose of harassing her.
} 
- Torture in case of not paying the alimony (Qapanchi, 2000, 162/5).

Therefore, when an individual must perform an obligatory act but refuses to do it, he can be tormented according to these arguments.

Some believe that if the accused is silent and does not answer the questions he is asked and his silence means non-recognition of the religious judge, then he deserves to be punished and if his action is for delaying the court or dodging to tell the truth, again he should be punished (Yazdi, 1986: 5).

With this explanation, it is clear that the accused who dodges to answer the questions deserves punishment for not performing his duty. Other Shiite scholars believe that the Muslim ruler can torture the person who hides the truth if he knows it briefly or considers its probability as strong and concealing that truth is also detrimental to Muslims. Here, punishment and torture are fair to achieve what he seeks.

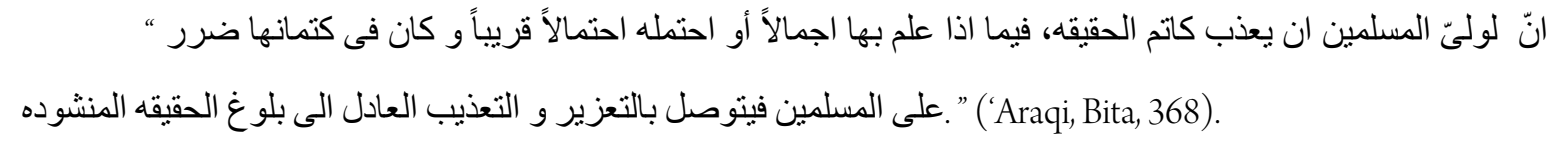

The rule of retaliation in kind

This rule somewhat satisfies and controls the spirit of human revenge but at the same time plays a more important role as an inhibitory factor. This rule has shown its importance in many jurisprudential and legal rules and has documentation from Quran (Ma'idah: 45; Baqarah: 178) and also narratives that have been approved by the custom and reason and the manner of intellectuals has also confirmed it. In the most obvious argument of this rule, Quran says: "فمن اعتدى عليكم فاعندو ا عليه بمثل ما اعتدى عليكم" (Baqarah: 194).

Sahib Jawahir says following this verse: "و الحرمات قصاص أى يجوز القصاص فى كل شى" (Najafi, 1988, $32 / 21)$.

Further, it is mentioned in another verse: "و جز اء السيئه سيئه مثلها" (Shura: 40).

In other narratives, it is said: “ردّو الحجر حيث جاء فان الثرّ لايدفعه الَّا الثرّ" (Ja’fari, 2007: 160).

Hence, it can be stated that retaliation in kind is an innate matter and a customary and rational principle upon which people have agreed. This rule lies in the conscience of human beings and has been mentioned in many verses and narratives in the meaning of the holy legislator and if people of one government are tortured under another government, the first government can also torment the citizens of that country.

\footnotetext{
${ }^{5}$ The man likens his wife to the back of his mother.
} 


\section{Review of documentation for the permissibility of torture}

From the previous discussions, it is concluded that while torture is an instance of oppression and violation of human dignity and any act considered as oppression is condemned in the teachings of Islam, based on some of the arguments and events of the early history of Islam, the permissibility of torture can be justified or even considered as necessary. Additionally, some other, with a personal impression of silent texts, believe that the permissibility of torture is rational. In this section, these documents are reviewed and analyzed in order to reveal the order of torture in Islamic teachings.

\section{Review of direct arguments for the permissibility of torture}

Case of Kinana ibn Abi al-Haqiq

This story tells the fact that the supporters of the permissibility of torture have ignored a fundamental point: The Prophet did not offend Kinana before discovering the objects. But he initially asked him and put him under obligation for a second time and some people also witnessed. Then, the Prophet went to the intended place and by doing this, the violation of promise by Kinana was revealed. Thus, Kinanal left no respect for himself as a result of violating his promise and accepting its consequences and because of this crime (violation of promise), he was punished.

Another delicate point is that despite being aware of the issue, the Prophet did not issue a torture order before the discovery of the property in order to respect the promise.

The case of Ibn Rabi'

There are some shortcomings concerning the argument for the permissibility of torture in this story:

a. Documentation of this story is weak because historical narratives are transmitted.

b. At the very beginning, it was stipulated by the Prophet that if Ibn Rabi' has hidden the property, he will be killed and ten of the Jews also witnessed. Hence, this historical narrative is related to a particular case. Accordingly, we cannot rely on this historical narrative to compare the permissibility of torture for a Muslim. 
The case of Hatib bin Abi Balta'ah

This woman was not accused but was a criminal (war spy) and the Prophet informed Ali (AS) that the woman has taken the letter and has moved to Mecca. Now, she is threatened to return the letter that includes military secrets and has been sent to Quraysh and the comparison of this non-Muslim offender with the Muslim accused is not accepted.

Mutilation in the case of Uhud

In connection with the intention to mutilate 70 people from Quraysh by the Prophet (PBUH), there are several essential points:

First, the issue of mutilation has been mentioned in Surah Nahl and occasion of revelation of Uhud war while this surah is meccan and Uhud war has occurred in Medina (Behjatpour, 2008, 58/1). So, there is no connection between this surah and Uhud war.

Second, this issue is in conflict with the manner of the Prophet since he gave priority to devotion and forgiveness in many wars, like the Conquest of Mecca in which the Prophet liberated all the polytheists.

Third, in numerous hadiths, great attention has been paid to the dignity of mankind and prohibition of oppression to others and in the case of mutilation, there is the explicit wording that has forbidden it.

Fourth, the existing narratives about mutilation in Uhud war are different in content, which is a sign of weakness. Besides, most of them have valid documents.

Fifth, in some narratives, the phrase "I mutilate" has been attributed to the Prophet's disciples not the Prophet himself.

Hadith of nail

This hadith has been provided with various phrases in the texts, which shows the weakness of this narrative and more importantly, this narrative contradicts the manner of the Prophet (PBUH) and has explicitly been rejected in the words of Imam Baqir (AS). Moreover, it has been stated that this fake hadith is completely false and has been used by liars as a means for the permissibility of torture by caliphs. In the book "Elal al-Sharaye'”, it is written: " عن ابى جعفر عليه السلام: ان اوّل من استحلّ الامر اء العذاب لكذبه كذبها انس بن مالك على رسول الله صله "سمّر يد رجل الى الحائطو من ثم استحلّ الامر اء العذاب (Sadouq, 2007, 541/2). 
Imam says: The first thing that caused the rulers to consider torture as permissible was the lie told by Anas bin Malik about the Prophet, stating that the Prophet nailed a man's hand to the wall and that is why the torture became permissible by the rulers.

\section{Imam Sadiq (AS) statement}

This narrative is cited for the permissibility of torture:

A) In relation to the permissibility or prohibition of torture, it is silent and conveys nothing about this issue because the appearance of the question is such that the permission for punishment has been given after knowing about the theft of the property and proving it through witnessing or confessing and with the purpose of returning the same property to the original owner rather than obtaining confession and proving the crime.

B) In the text of the narrative, the discussion of influence or non-influence of confessions resulting from torture has been raised. Additionally, the thief has offered the stolen property. Hence, the subject of the question is to amputate the hand of the thief not the issue of torture.

In criminal sentences, if the offender is found guilty through other evidence like witnessing, the execution of the sentence will be certain. Therefore, the question is whether the amputation is performed in case of offering the stolen property. Imam answered: Yes.

$$
\text { ” لايدل على أنه ضرب على الاقرار بل ظاهر السؤال انه علم سرقته بيينة أو اقرار و انما ضرب على رد المال، }
$$

(Fazel Hendi, 1985, 528/2).

C) Some believe that in this particular case, the act of beating (and torturing) has been committed by the owner of the property and has no relation to the judge and the law (Sadeqi, 2014: 67).

\section{$\underline{\text { Review of indirect arguments }}$}

The rule of necessity

Reliance on the rule of necessity is not enough for the permissibility of torture since one of the conditions of the rule of necessity is that its execution should not be incompatible with others' interests. As can be inferred from the instances of the rule of necessity in verses and narratives, the channel of this rule is through preserving and protecting the self by eating carrions and such instances and for this reason, the main discussion of necessity is in the book on eating and drinking, which includes conditions such as eating as much as bare subsistence (Vaeli, 1983: 194). 
Another point is that the conditions for the realization of emergency situations are as follows:

Being afraid of self-damage

Being afraid of self-damage because of illness

Being afraid of damage to others (Ansari, 1999, 438/3)

By carefully considering the issue of torture, it is revealed that torture does not involve any of these instances.

The rule of the important and the more important

The conflict between the important and the more important and the use of preferences in this conflict and priority of the more important are the issues discussed by many thinkers, and the manner of intellectuals has always respected this subject. This rule has also solved a number of important problems. As a result, all religious and secular schools, according to their foundations, have accepted the entirety of this rule. But what should be precisely explained and viewed with caution regarding the issue of torture and reliance on this rule is the correct identification of the instance of the more important and also the selection of the accepted components and delicate standards to determine the more important and its preference to the important.

With a sharp and reasonable look, it can be understood that torture is one of the affairs that disturb the security and psychological well-being of society and if this phenomenon is common in a society (either legally or illegally), it will lead to deprival of peace and spread of anxiety and insecurity in privacy and at the community level. The outbreak of this plague, in turn, will result in lack of credibility and weakness of the criminal system which should be a refuge for the oppressed and vulnerable people of the society. This point will change the instances of the important and the more important since no common sense accepts that people live in fear to prevent a matter whose importance is less than maintaining the reverence for the law and preventing the damage caused by the invalidity of laws (Shafi'ei-niya, 2009: 184). Particularly in this period of time when the dignity of Islam and the Islamic Revolution is subject to the invasion of the enemy, we should take into account the equations of the conflict and the selection between the important and the more important in dignity and grace of Islam and the Revolution and also Islam's reliance on principles and values. It is likely that in some cases, it is necessary to sacrifice the fleeting power and rule to Islam (Salavati, 1991, 586/3).

The rule of the avoidance of the more corrupt by the corrupt one

Reliance on this jurisprudential rule, like the rule of the important and the more important, among the 
supporters of the permissibility of torture requires a thorough examination because accusation to a person and the possibility of mischief cannot merely provide the permissibility of torture and if it is permissible, it needs a solid reason and the tortured one should as far as possible be an instance of corruption and the ranking of the corrupt and the more corrupt should be in relation to the expedience of the Islamic state. In other words, one must carefully determine which one is an instance of the corrupt or the more corrupt.

In the final session of formulating the constitution of the Islamic Republic, in response to the rule of the avoidance of the more corrupt by the corrupt one, Dr. Beheshti, the profound-thinking scholar, states:

The problem is to open the way for something. As soon as this way is opened and they wanted to slap the person who is accused of the biggest crimes, be sure that this will lead to the cauterization of all individuals. So, this way should be closed. That is, if ten prominent people are kidnapped and this way is not opened, society will be healthier. (Proceedings of the negotiations of the constitutional assembly, 1985, 778/1)

The corruption caused by non-torture can at most result in assassinating some of the most important characters or exploding some of the vital centers. Although these consequences have a lot of corruption, in the comparison between the profits and losses of torture, the common sense decides that the corruption caused by the lack of one or more prominent characters is not less than the corruption resulting from the creation of an improper practice that threatens humanity (Shafi'ei-niya, 2009: 184).

Torture in terms of politics

In the opinion of Shiite and non-Shiite jurisprudents concerning politics, torture is permissible to protect the government. But this permission may reduce the political life of the government since if torture becomes a common policy for the government, the security of people even the supporters of the government will be lost and its effects and consequences will emerge in society in the long run, which may weaken the government's popular base. The question is whether throughout history, political rulers have gained more benefit from the application of torture during their political life or from the abandonment of torture? If this was an efficient way throughout history, many of the governments that had used this practice should have a better situation while experience and history show otherwise.

On the other hand, the assumption that the maintenance of the Muslim system is subject to the punishment of a defendant is an extremely rare assumption because no one can ever have information that disrupts or destroys the Muslim system. Besides, torture causes the system's weakness since a system should be so weak that it preservation is dependent on the punishment of the accused. Furthermore, the issue of maintaining the dignity of Islam should not be considered to be less than preserving the system (Salavati, 1991, 577/3). 
Moreover, torture in terms of politics may lead to false confession and information in many cases (Levin, 1978: 148). In this case, the purpose of torture has been violated and it is likely that the feeling of pain in torture reaches the degree in which the individual chooses the shortest path (confession) for temporary relief from pain. This issue was stated by the Prophet in relation to the Muslims who had taken two captives: Whenever they tell you the truth, you beat them and when they tell a lie, you release them (Ibn Hisham, 1963, 449/2).

Torture due to quitting the obligatory matter

In this argument, there are two ways to apply torture:

a. Some people have mentioned that the punishment of the crime of concealing the truth and quitting the obligatory matter are instances of Ta'zir but have not stated any rule or law for the nature of torture in the criminal laws of Islam.

b. Some people have also considered torture as the penalty of the crime of quitting the obligatory matter and state that this issue can be implemented for concealing the truth while relying on the narratives saying that people quitting the obligatory matter deserve torture.

Thus, the issue of torture disappears and turns into punishment, which is excluded from the instances of torture both in jurisprudence and domestic and and foreign laws.

The rule of retaliation in kind

Here, it should be noted that the implementation of the rule of retaliation in kind has a specific relation to its subject (civil or criminal) since in legal and civil matters, the losing party cannot act directly and without the ruler's order and only in retaliation, there is no need for the ruler's permission (Naraqi, 1994, 453/17). Therefore, this rule is not universal because in many cases, jurisprudents do not allow the victim to do a prohibited act (the same as the crime). Ayatollah Khoei writes:

If from the verse of encroachment (E'teda), it is inferred that the victim can commit retaliation (beating), it is not correct because the use of these verses does not include the punishment through a forbidden act. (Khoei, $1992,344 / 1)$

\section{CONCLUSION}

Based on the foregoing, it becomes clear that the prohibition of torture in the criminal laws and criminal 
jurisprudence of Islam is uncertain. Despite the fact that torture is incompatible with the teachings of Islam and its legal principles and in many resources, it has been regarded as an instance of oppression and violator of justice, it seems that some of the arguments of the supporters of the permissibility of torture in Islam are not much invalid. Although a large number of the supporters' arguments for the permissibility of torture can be answered, some arguments (e.g. the case of Kinana, torture in terms of politics and maintaining the authority of Islam) cannot be easily answered. Further, the existence of phrases in the statement of jurisprudents, such as the ruler's assurance about the offender's crime, granting permission by the fully-qualified jurisprudent, non-negligibility of the instance of the more important and passed expediency and torture and punishment of the offender to tell the truth, suggest this hypothesis that many Muslim scholars believe in limited permissibility of torture. Although they state that the permissibility of torture is subject to strict conditions which in practice may not be possible, this cannot provide an exception to the prohibition of torture.

Thus, we can accept this hypothesis that the permissibility of torture in Islamic laws has been accepted as a particular affirmative proposition and by precisely observing and applying some points, the limited permissibility of torture is accepted.

This research can be the basis of many hypotheses and theories of researchers and scholars in this topic, thereby providing numerous scientific and research points to the lovers of knowledge in the field of jurisprudence and Islamic law.

\section{UMA REVISÃO DOS ARGUMENTOS JURISPRUDENCIAIS PARA A PERMISSIBILIDADE DA TORTURA NO ISLÃ}

\section{Resumo}

A dignidade humana é o aspecto comum de todas as religiões divinas. A tortura é uma questão que tem como alvo a dignidade humana. Assim, é lembrado como crime contra a humanidade em muitas culturas e regras. O Islã sempre insistiu no respeito pelos humanos. Mas em fontes islâmicas, há documentos (incluindo argumentos diretos e indiretos) que transmitem à consciência a permissibilidade da tortura e fazem a audiência duvidar ou pelo menos admitir essa possibilidade. O pensamento profundo sobre seus princípios pode ser responsivo a essas ambiguidades. O presente estudo é uma pesquisa nova e fundamental que tem sido conduzida com base em estudos bibliotecários e procura responder, explorar e desmistificar os argumentos para a permissibilidade da tortura. O estudo da documentação demonstra que a hipótese de permissibilidade à tortura no Islã foi aceita como uma "proposta afirmativa em particular". A necessidade deste tipo de pesquisa é que a jurisprudência dinâmica, ao responder aos desafios, deve ativamente explicar suas posições com fortes argumentos.

Palavras-chave: Tortura, Islamismo, Argumentos, Permissibilidade 


\section{REFERENCES}

ARAQI, Z. (n.d.). Kitab al-Qaza' Sharh Tabsirat al-Muta'allimin. Research by M. H. Ma'refat. Qom: Matba'a mehr, Bita.

A GROUP OF RESEARCHERS, (2010). Dictionary of jurisprudential principles. First Edition, Qom: Publication of the Research Institute of Islamic Sciences and Culture.

AHMADI MIYANJI, M. A. (2001). Information and research in Islam. Tehran: Dadgostar Publishing.

AL-MOUSELI, A. (n.d.). Position of Abu 'Ali. Research by H. Salim Asad. Damascus: Dar al-Ma’moun, (Bita).

ALOUSI, Sh. (n.d). Interpretation of the spirit of meanings (Alousi). (Bita), Bija.

AL-SANAD, M. (2005). Investigating the political system of imamiyyah. Research by M. H. Razavi \& M. Eskandari. First Edition, Qom: Baqiyat Publishing.

AMELI, J. M. (2005). Al-Sahih min Sirat al-Nabi al-A'zam. First Edition, Qom: Dar al-Hadith.

ANSARI, M. A. (1999). Al-Musu'a al-Faqihiya al-Moysara. First Edition, Qom: Majma' al-Fikr al-Islami.

BAHRAMI, M. \& Faramarz Qaramaleki, A. (2013). Conceptual analysis of moral conflicts. Ethics and Medical History, Tehran University of Medical Sciences, 5(2).

BAIL, Ch. (2012). Al-Ta'zib al-Taharrob min al-Masooliyya. Translated by M. J. Al-Azraqi. First Edition, Markaz Dirasat al-Wahda al-Arabiyya.

BARQI, A. B. M. (1951). Al-Mahasen. Research by J. Hoseini. First Edition, Tehran: Dar al-Kutub alIslamiyyah.

BECCARIA, C. (1989). Treatise on crimes and punishments. Translated by M. A. Ardebili. Second Edition, Tehran: Shahid Beheshti University Publication.

BEHJATPOUR, A. K. (2008). Along with revelation, the first comprehensive interpretation of Shi'a in order of descent of Quran. First Edition, Qom: Sabt al-Nabi (AS).

CASSESE, A. (1998). Inhuman governments. Translated by K. Tabatabaei. First Edition, Be’sat Publishing.

FAZEL HENDI, B. (1985). Kashf al-Lytham. Qom: Publication of Ayatollah Marashi Library.

FEIZ KASHANI, M. (1995). Tafsir-e-Safi. Second Edition, Qom: Maktabat al-Sadr, Al-Hadi Institute.

GHAZZALI, H. M. (n.d.). Ihya al-Ulum. Beirut: Dar al-Kitab, Bita.

HELLI, H. B. Y. (1992). Qawa'id al-Ahkam. First Edition, Qom: Islami Publishing. 


\section{Holy Quran}

HORRE AMELI, M. B. H. (1993). Wasail al-Shia. Second Edition, Qom: Al al-Bayt.

IBN ABEDIN, M.A. (1994). Hashiyeh Radd al-Muhtar. First Edition, Beirut: Dar al-Fikr.

IBN ASIR, M. (1985). Al-Nihayah fi Gharib al-Hadith wal Athar. Research by A. Al-Zawi and M. M. AlTanahi. Fourth Edition, Qom: Ismaili Institute Publishing.

IBN BABUYEH QOMI (SADOUQ), M. B. A. (1983). Al-Khisal. Second Edition, Qom: Islami Publishing

IBN BABUYEH QOMI (SADOUQ), M. B. A. (1984). Someone who is not in the presence of the jurisprudent. Edition and annotation by A. A. Ghaffari. Second Edition, Qom: Islami Publishing.

IBN BABUYEH QOMI (SADOUQ), M. B. A. (2007). Elal al-Sharaye'. Research by M. S. Bahr al-Ulum. Najaf: Maktab al-Heydariyeh Publishing.

IBN HISHAM, A. M. (1963). Prophetic manner. Research by M. M. Abdulhamid. Cairo: Maktaba Sabih Publishing.

IBN TARIYAH, M., Orveh, A. \& Bajavi, Y. (2003). History of torture and principles of prohibition in Islam. Damascus: Markaz al-Rayat Lel-Tanmiya al-Fikriyah.

IMAM ALI (AS). (2007). Nahj al-Balagha. Translated by M. T. Ja'fari. First Edition, Tehran: Publication of Entrepreneurs of Culture and Art.

ISLAMIC CONSULTATIVE ASSEMBLY (1985). Proceedings of the negotiations of the constitutional assembly. First Edition, Tehran: General Directorate of Cultural Affairs and Public Relations of the Islamic Consultative Assembly.

KHOEI, A. (1991). Misbah al-Fuqaha. First Edition, Davari Publishing

KHONJI ESFAHANI (IBN ROUZBEHAN), F. (1983). Suluk al-Muluk. Edition and introduction by M. A. Movahhed. First Edition, Tehran: Kharazmi Publishing.

KOURANI, A. (2006). Human rights for the Ahlul Bayt. First Edition, Qom: Markaz al-Mustafa al-Dirasat alIslamiyyah, Dar al-Hoda.

LEVIN, L. (1998). Questions and answers about human rights. Translated by M. J. Pouyandeh. First Edition, Tehran: Qatreh Publishing.

MAJLESI, M. B. (1983). Bihar al-Anwar. Second Edition, Beirut: Al-Wafa Institute.

MAVERDI, A. H. (2004). Al-Ahkam al-Sultaniyyah (Rules of governance). Translation and research by H. Saberi. First Edition, Tehran: Scientific and cultural publication.

MESHKINI, A. (2015). Terminology of the science of principles. Translated by A. R. Shah Fazl. First Edition, 
Qom: Boustan-e-Kitab.

MONTESQUIEU, Sh. (1970). Spirit of laws. Translated by A. A. Mohtadi. Sixth Edition, Tehran: Amir Kabir Publishing.

MOTAHHARI, M. (1991). Islam and time requirements. First Edition, Tehran: Sadra.

MOTTAQI HENDI, 'A. (n.d.). Kanz al-Ummal. Edition by Al-Sheikh Bakri Hayani \& Al-Sheikh Safvat al-Safa. Beirut: Al-Risala Institute (Bita).

MOUSAVI KANTOURI LAKENHOI, M. Q. (n.d.). Tashyeed al-Mata'en li Kashf al-Dhaghaen. Bija, (Bita).

MOZAFFAR, M. R. (1981). Principles of jurisprudence. First Edition, Qom: Islami Publishing.

NAJAFI, M. H. (1988). Jawahir al-Kalam. Research by A. Qouchani/Edition by M. Akhoundi. Third Edition, Tehran: Dar al-Kutub al-Islamiyyah.

NARAQI, A. (1994). Musnad al-Shia. First Edition, Qom: Al al-Bayt.

PEYMANI, Z. (1977). Judicial arguments in French revolutionary law. Tehran: Ganj-e-Danesh.

QAPANCHI, H. (2000). Position of Imam Ali (AS). Research by T. Salami. First Edition, Beirut: A'lami Publishing.

RAVANDI, Q. (1989). Al-Kharaej val Jaraeh. Qom: Institute of Imam Mahdi (AS).

SADEQI, Gh. A. (2014). Obtaining confessions through torture and comparing it with human rights and domestic law. Third Edition, Tehran: Mizan.

SALAVATI, M. (1991). Jurisprudential foundations of the Islamic government. First Edition, Qom: Fekr Publishing.

SAMAKIYYA, M. H. (1970). Hajiyyah al-Iqrar fi al-Ahkam al-Qazaeiyyah. First Edition, Baghdad: Bina.

SHAFE'EI, M. B. E. (1983). Kitab al-Umm. Second Edition, Beirut: Dar al-Fikr.

SHAFI'EI-NIYA, M. Sh. (2009). Comparative study of the principle of torture prohibition in the three systems of Islam, Iran and international law. First Edition, Tehran: Strategic Studies Institute.

SIVARI, M. B. A. (1983). Nazad al-Qawa'id al-Fiqhiyyah. Research by A. L. Koohkamarei. First Edition, Qom: Publication of Ayatollah Mar'ashi Library.

TABATABAEI, M. H. (2017). Al-Mizan fi Tafsir al-Quran. Third Edition, Tehran: Dar al-Kutub al-Islamiyyah. VAELI, A. (1983). Prison sentences in Islam. Translated by M. H. Bokaei. Tehran: Islamic culture publishing. VAQEDI, M. (1985). Al-Maghazi. Research by M. Jones. Qom: Islamic Knowledge Publishing. 
YAZDI, M. (1986). A series of articles on description and interpretation of the constitution. Resalat NEWSPAPER, No. 169 (Archive of Astan Quds Razavi Documentation Center).

Zahabi, Sh. (1987). History of Islam. First Edition, Beirut: Dar al-Kitab.

Trabalho enviado em 14 de julho de 2018.

Aceito em 24 de julho de 2018. 